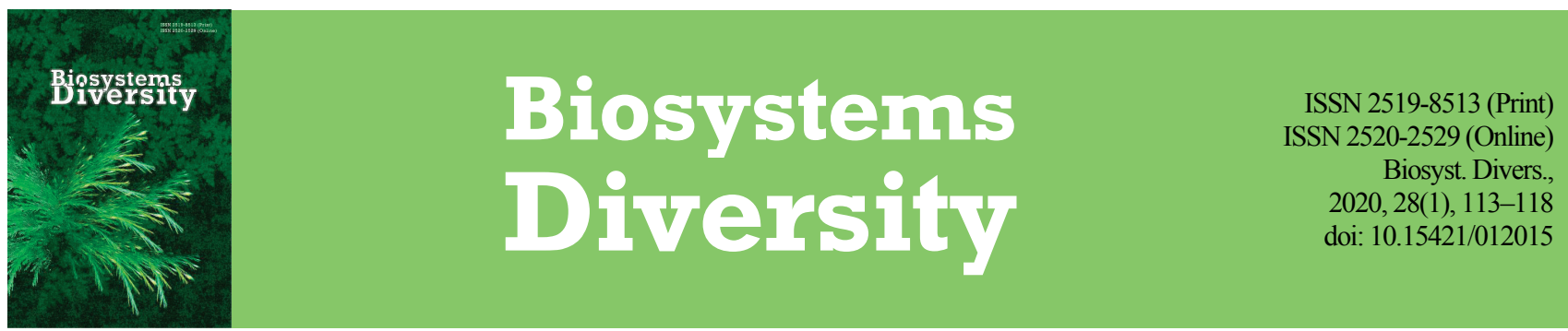

\title{
The effect of soil and climatic conditions on the distribution of nutrients in Actinidia arguta leaves
}

\author{
N. V. Zaimenko*, N. V. Skrypchenko*, B. O. Ivanytska*, D. O. Klymchuk**, N. S. Novychenko**, D. Liu*** \\ *M. M. Gryshko National Botanical Garden of the National Academy of Sciences of Ukraine, Kyiv, Ukraine \\ **M. G. Kholodny Institute of Botany of the National Academy of Sciences of Ukraine, Kyiv, Ukraine \\ ***Jiamusi University, Jiamusi ,China
}

Article info

Received 23.01.2020

Received in revised form 20.02.2020 Accepted 21.02.2020

M. M. Gryshko National Botanical Garden of the National Academy

of Sciences of Ukraine,

Timiryazevska st., 1 ,

Kyiv, 01014, Ukraine

Tel.: + 38-068-686-24-09.

E-mail:zaimenkon»@ukr.net

M. G. Kholodny Institute

of Botany of the National

Academy of Sciences of Ukraine,

Tereshchenkivska st., 2 ,

Kyiv, 01004, Ukrain

Tel:-38-044-234-13-43. E-mail:

microscopy.botany@gmail.com

Life Science Collage, Jiamusi

University, Xue Fu st., 148,

Jiamusi, 154007,

Heilongjiang, China

Tel.: +861-384-618-18-72.

E-mail: liudejiang2004@163.com

\section{Introduction}

Presently kiwiberry (Actinidia arguta (Siebold \& Zucc.) Planch. ex Miq.) is becoming increasingly popular among consumers and manufacturers in many countries around the world. The kiwiberry fruits are used both fresh and as a raw material for the production of dried fruits, compotes, juices, jams, wines. Numerous studies have shown a high content of biologically active substances, vitamins $(\mathrm{C}, \mathrm{E}, \mathrm{K})$, polysaccharides, polyphenols, triterpenoids, alkaloids in fruits. They are characterized by analgesic, antibacterial, antioxidant, antitumour and other pharmacological activities (Niu et al., 2019; Qing et al., 2019). As a commercially cultivated plant kiwiberry is the most popular in New Zealand, USA, Japan, Belgium, Germany, Italy and Poland. A significant contribution to the popularization and selection of kiwiberry in Ukraine was made by researchers of M. Grishko National Botanical Garden of the National Academy of Sciences of Ukraine (NBG), who created 20 high-yield cultivars promising for industrial and household cultivation (Skrypchenko \& Latocha, 2017).

The study of the ecology of nutrients is now becoming increasingly important, since it is known that in different soils mineral compounds are almost never found in such quantities and in such balanced proportions that would be optimal for growth and development of plants (Zaimenko, 2008; Jankowski et al., 2018a, 2018b; Loza et al., 2018;
Lykholat et al., 2018). The latter always compensate for the negative effects of the environmental stress factors by triggering adaptive changes in the plant nutrition and other physiological processes (Zaimenko, 2019). Soils, in turn, are characterized by varied nutrient content, which determine the chemical composition of plants. At the same time, the effect of mineral compounds on the growth and development of plants depends on the physical, chemical, and biological parameters of the soil, as well as on the external conditions and physiological adaptation of organisms (Sing et al., 2017).

The main prerequisite of adaptation is the internal processes that occur in the biosystem and ensure the stability of its external functions relative to various environmental parameters (Voloshin \& Subbotin, 1987). There are two types of adaptations: those supported by all structural elements of a certain system level, and compensation. Stable adaptive mechanisms ensure the adaptation of the plant organism to certain environmental conditions, which remain constant for a lasting period of time. The labile adaptive mechanisms make it possible to adapt to irregular relatively short-term changes in the environmental conditions (Korniyenko et al., 1965). The combined functioning of these two groups of adaptive mechanisms ensures the maximum adaptation of plants to specific conditions with minimal loss of energy. Moreover, the ability of plants to regulate the up-take and assimilation of nutrients and the possibility of using them to control metabolic processes and the 
synthesis of biologically active compounds is of particular importance. The nutrient content in soil and plants is one of the most important components of the macro- and microelement circulation in the ecosystem. Plant growth and development depend on environmental conditions, so the availability of nutrients is determined not only by their concentration in soil solution, but also by their combined effect on the physiological processes in plants. Differences in the content of macro- and microelements significantly affect the photochemical processes, and therefore, they are crucial for plant development. Nevertheless, the mechanisms involved in the accumulation and remobilization of elements of mineral nutrition in the tissues and organs of plants remain still unclear.

Only fragmentary data are available, for example, regarding differences in the distribution of mineral nutrition elements in the foliar tissues affected by phytopathogens (Belan et al., 2015). The studies using $\mathrm{x}$-ray microanalysis showed that out of the thirty three mineral elements found in the leaf tissue only distribution of potassium and calcium changed along the perimeter of the lesion. The highest potassium content was found in asymptomatic leaf tissues, decreasing in the direction of the transition zone and reaching minimal values in symptomatic tissues. And, on the contrary, the highest level of calcium was recorded in symptomatic tissues, decreasing in the direction of the transition zone and reaching minimal values in asymptomatic tissues surrounding the foci of lesions caused by phytopathogens.

More recent studies using microprobe x-ray fluorescence spectrometry $(\mu-\mathrm{XRF})$, revealed the accumulation of selenium, calcium, potassium, copper and manganese in necrotic areas of leaves affected by phytopathogens (Silva et al., 2018). In contrast, sodium was evenly distributed in leaf tissues. In addition, the fluorescent method turned out to be quite informative in the case of a hierarchical assessment of differences in the content of nutrients by chlorophyll indices (Kalaji et al., 2018). The results of the analysis of the distribution of macro- and microelements in tissues during aging and leaf modulation are also noteworthy (Maillard et al., 2015). It was found that, regardless of the plant species, calcium and manganese, unlike other elements, are mainly mobilized from roots to shoots. A number of authors identified proteins involved in the regulation of plant nutrition by zinc, manganese and phosphorus, ensuring their remobilization between leaves and shoots (Dong et al., 2018). It was proved that the transport and distribution of zinc and cadmium in tissues clearly differed between legumes and cereal plant species, although the effect of high zinc concentrations on cadmium transport was less pronounced (Tûma et al., 2019). At the same time, a high concentration of zinc in the nutrient medium negatively affected the remobilization of this element from the root to the shoot and from the oldest to the youngest leaves. Jamaji \& Ma (2014) identified four different strategies in the remobilization of mineral nutrients: xylemswitch, phloem-tropic, phloem-kickback and minimum-shift, based on specific molecular transport processes. Interesting results were obtained by Wang et al. (2019) when studying the effect of phenolics on the remobilization of macronutrients in wound tissues. In particular, the low synthesis of phenols contributed to an increase in the level of nitrogen in plants and a decrease in the supply of phosphorus and potassium. The application of $\mathrm{Fe}_{3} \mathrm{O}_{4}$ nanoparticles positively affected the accumulation of phosphorus, potassium, calcium, manganese, and iron in the roots, stems, and leaves of plants (Souza et al., 2019).

Since the concentration of macro- and micronutrients in plant tissues is the most reliable indicator of the chemical state of plants, which provides for the control of a large number of other factors, we studied the distribution of biogenic elements in the leaves of the woody vine of kiwiberry. It should be noted that the quantitative analysis of chemical elements is also a reliable criterion for assessing the imbalance in species of various ecomorphotypes, in particular, the $\mathrm{Ca}: \mathrm{Mg}$ ratio is much higher in woody vines.

\section{Materials and methods}

The object of the study was generatively mature plants of kiwiberry (Actinidia arguta): 'Sentyabrskaya', 'Krasunya', 'Kievskaya krupnoplodnaya' and 'Perlina sadu' cultivars, grown under different soil and climatic conditions, namely: in Ukraine (Kyiv city, NBG) on grey forest soil and in China (Jiamusi University, Heilongjiang Province) on black earth. Leaf and soil samples were collected during fruit ripening stage. The distribution of nutrients in leaf tissues was determined using scanning electron microscopy. Dehydrated samples were placed on aluminum or graphite plates, coated by gold film $5 \pm 2 \mu \mathrm{m}$ thick. Then, the samples were placed on titanium plates and analyzed using a JED-2300 X-ray spectrometer integrated with a JSM 6060 LA scanning electron microscope.

The morphometric measurements were carried out using electron microscopic images. The surface of stomatal cells and their number per unit of leaf area was evaluated using UTHSCA Image 3.0 by electron microscopic negatives scale.

The total content of mineral elements in the soil was analyzed using an iCAP 6300 Duo optical emission JCP spectrometer. The soil organic compounds were extracted by maceration in acetone, and afterwards, identified by Agilent 1100 DAD-HPL $+\mathrm{C}$ chromatographic system using an Agilent Zorbax Eclipse Plus CL8 column.

The photosynthetic pigments (chlorophyll $a, b$ and carotenoids) were extracted by dimethylsulfoxide (DMSO): $200 \mathrm{mg}$ of sample leaf tissue was poured into $5 \mathrm{~mL}$ of DMSO, kept in a thermostat for 12 hours. Their content was determined spectrophotometrically (Wellburn, 1994) by Specord 2000 (Analitic Jena), at wavelengths: $480 \mathrm{~nm}$ for carotenoids, 649 and $665 \mathrm{~nm}$ for chlorophyll $b$ and $a$, respectively. Anthocyanins were extracted from the leaves by $0.1 \mathrm{~N} \mathrm{HCl}$. Their content was determined spectrophotometricaly at the wavelength of $490 \mathrm{~nm}$ (Pisarev et al., 2010).

Bioelectric potential (BEP) of plants was determined using redox electrodes by potentiometric and conductometric analytic techniques (Martynenko, 1988). The BEP was measured by the surface abstraction method with silver chloride electrodes of the EVL-1M3 grade and an electrometric transducer. This method allows one, firstly, to study the native electrical characteristics of the whole plant, and, secondly, it doesn't have drawbacks characteristic to contact methods such as intrusion into the thermal and gas regime of the leaves.

The groups of values were compared by U-criterion Mann-Whitney. This is a statistical criterion used to assess differences between two independent samples, allows us to identify differences in the parameter value between small samples for $\mathrm{P}<0.05, \mathrm{P}<0.01, \mathrm{P}<0.001$. Quantitative indicators of the content of mineral nutrients in leaves and soil are given as arithmetic mean with standard deviation.

\section{Results}

The significant differences in the distribution of nutrients in the leaves of $A$. arguta plants, developed in the soil and climatic conditions of Kyiv and Jiamusi, were shown with the use of scanning electron microscopy. The leaves of plants of the Chinese plot were characterized by a higher concentration of mineral elements, except silicon. When studying the distribution of nutrients in leaves along the stem, the presence of three zones was revealed for the first time - the lower one saturates the roots, the upper one - saturates the leaves in the phase of active growth and the middle one, in which the assimilates are distributed in two directions. A directly proportional relationship was found between the biosynthesis of photosynthetic pigments and electrophysiological activity, especially for the leaves of the lower tier. With the presence of zones where there is a change in the polarity of bioelectric potentials and the distribution of assimilates, we can suppose there are different functional roles of individual parts of plants. In particular, the leaves of the lower tier perform a storage function. The middle part is less conservative and characterized by a high sensitivity to external factors. We marked it as a synthesis zone. The upper part is a zone of active growth. The results of a comparative analysis of the indicators of the number of chloroplasts in the leaf cell proved that the obtained dependence can be used as a diagnostic criterion for assessing the predicted plant productivity at an early stage of their development.

Currently, insufficient information is available about the relationship between the leaf and root nutrition of woody vines, including kiwiberry. The lack of information regarding the metabolic independence of various plant organs in the mineral nutrition system impedes the development of optimal technology for their cultivation, taking into account environmental factors. 
A comparative analysis of the distribution of nutrients in the leaves of kiwiberry grown under different climatic and soil conditions viz. in Kyiv city (Ukraine) on grey forest soil and in Jiamusi (China) on black
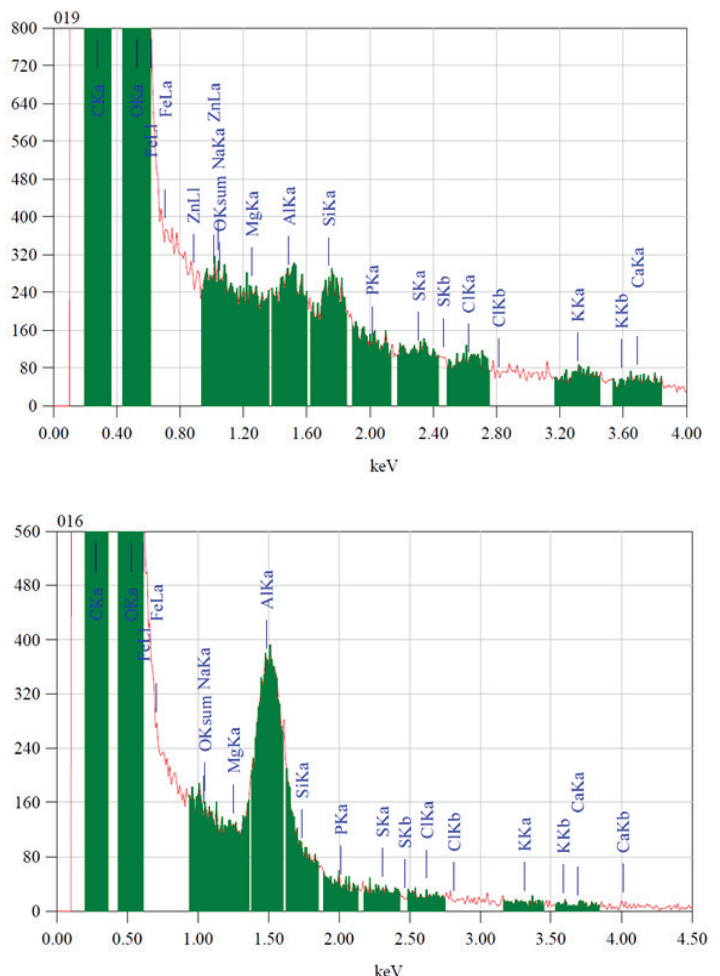

earth revealed significant differences in their concentration (Table 1). Figures 1 and 2 present information on the distribution of chemical elements in plant tissues of kiwiberry obtained by scanning microscopy.

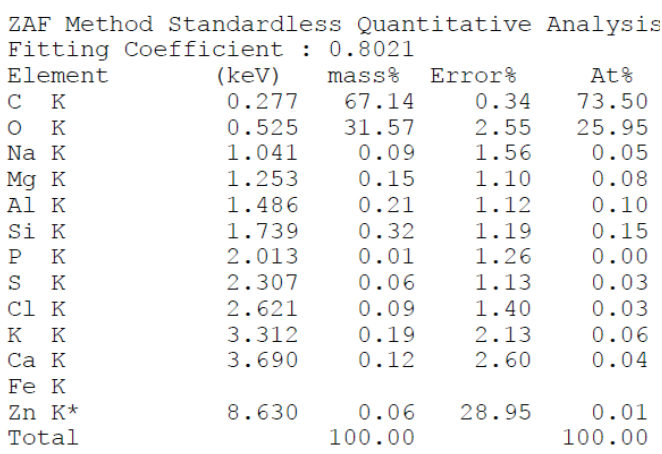

ZAF Method Standardless Quantitative Analysis Fitting Coefficient : 1.0011

\begin{tabular}{|c|c|c|c|c|c|}
\hline \multicolumn{2}{|c|}{ Element } & $(\mathrm{keV})$ & mass & Error\% & At $\%$ \\
\hline C & $\mathrm{K}$ & 0.277 & 50.31 & 2.40 & 58.50 \\
\hline 0 & $\mathrm{~K}$ & 0.525 & 44.41 & 10.57 & 38.77 \\
\hline $\mathrm{Na}$ & $\mathrm{K}$ & 1.041 & 0.09 & 7.49 & 0.05 \\
\hline Mg & $\mathrm{K}$ & 1.253 & 1.42 & 6.13 & 0.81 \\
\hline Al & K & 1.486 & 2.84 & 6.27 & 1.4 \\
\hline $\mathrm{Si}$ & $\mathrm{K}$ & & & & \\
\hline P & K & 2.013 & 0.63 & 7.00 & 0 \\
\hline S & $\mathrm{K}$ & 2.307 & 0.09 & 6.27 & 0 \\
\hline $\mathrm{Cl}$ & $\mathrm{K}$ & & & & \\
\hline K & $\mathrm{K}$ & & & & \\
\hline $\mathrm{Ca}$ & $\mathrm{K}$ & 3.690 & 0.16 & 14.01 & 0.0 \\
\hline $\mathrm{Fe}$ & K & 6.398 & 0.07 & 42.58 & 0 \\
\hline Tot & tal & & 100.00 & & 100 \\
\hline
\end{tabular}

Fig. 1. Distribution of biogenic elements in the leaves of A. arguta which grew in the conditions of Kyiv: scanning electron microscopy was used

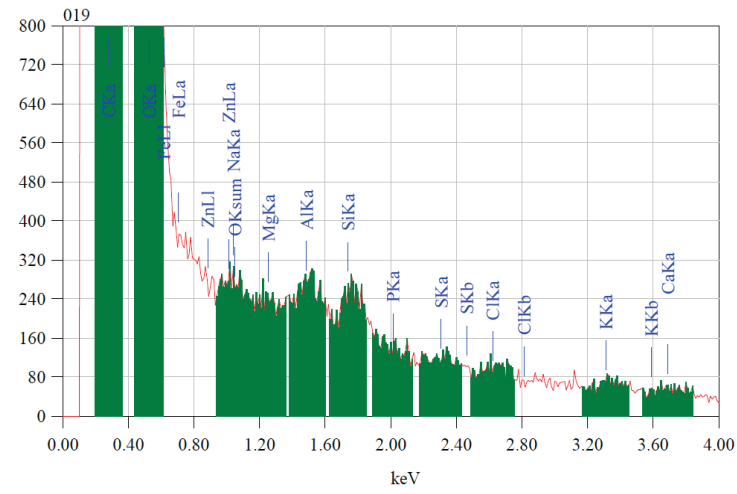

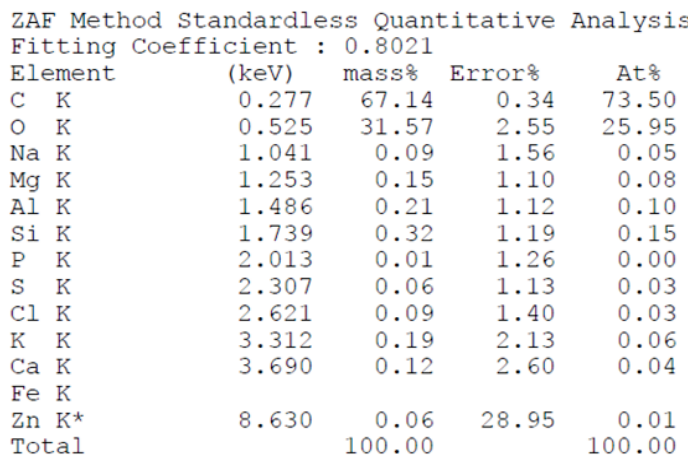

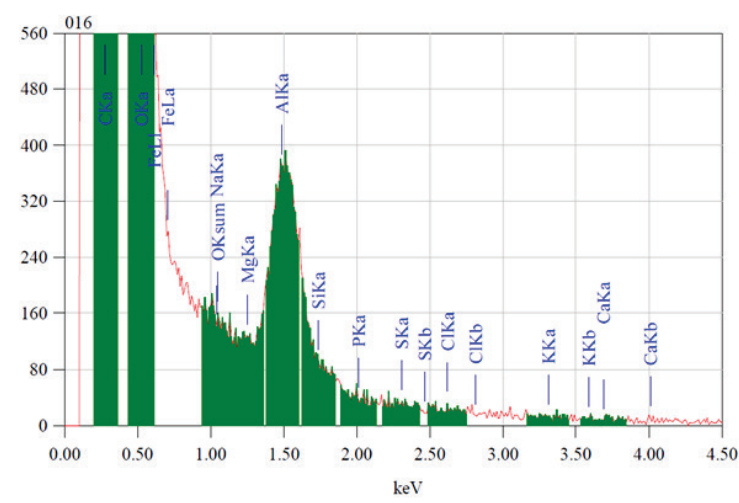

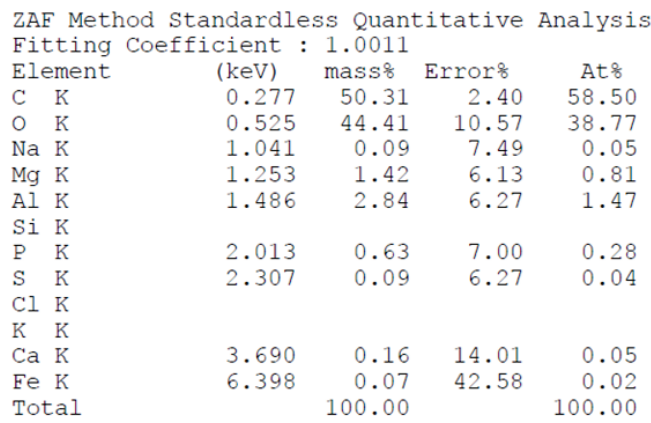

Fig. 2. Distribution of biogenic elements in leaves of $A$. arguta which grew in conditions of Jiamusi (Scanning electron microscopy was used)

The leaves of kiwiberry, especially of those from China, were characterized by a rather higher concentration of chlorine. In general, the tissues of the leaves of plants that grew under the conditions of Jiamusi were characterized by a higher content of nutrients, which is explained by the higher level of organic matter in the soil. In particular, the humus content in the experimental plots in the grey forest soil was $2.8 \%$, and in the black earth $-3.9 \%$. It is known that the leading role in the structure formation of humus belongs to pro-humic substances, primarily phenolic compounds. The results of our studies showed a higher concentration of low molecular weight organic compounds in the soil samples from China, especially terpenoids, the content of which was 10 times higher in comparison with samples of grey forest soil from Ukraine (Fig. 3). 
Table 1

Distribution of nutrient elements in $A$. arguta leaves (\% wet mass)

\begin{tabular}{ccc}
\hline \multirow{2}{*}{ Element } & \multicolumn{2}{c}{ Soil and climatic conditions } \\
\cline { 2 - 3 } & Kyiv & Jiamusi \\
\hline $\mathrm{C}$ & $62.00 \pm 2.83$ & $60.12 \pm 2.11$ \\
$\mathrm{O}$ & $36.63 \pm 1.25$ & $36.53 \pm 1.58$ \\
$\mathrm{Na}$ & $0.10 \pm 0.01$ & $0.73 \pm 0.04^{* *}$ \\
$\mathrm{Mg}$ & $0.24 \pm 0.03$ & $0.51 \pm 0.06^{* *}$ \\
$\mathrm{Al}$ & $0.34 \pm 0.04$ & $0.73 \pm 0.09^{*}$ \\
$\mathrm{Si}$ & $0.34 \pm 0.05$ & $0.16 \pm 0.02^{*}$ \\
$\mathrm{P}$ & $0.03 \pm 0.004$ & $0.25 \pm 0.04^{*}$ \\
$\mathrm{~S}$ & $0.06 \pm 0.005$ & $0.30 \pm 0.04^{*}$ \\
$\mathrm{Cl}$ & $0.08 \pm 0.007$ & $0.22 \pm 0.03^{*}$ \\
$\mathrm{~K}$ & $0.04 \pm 0.003$ & $0.21 \pm 0.04^{*}$ \\
$\mathrm{Ca}$ & $0.13 \pm 0.02$ & $0.21 \pm 0.05^{*}$ \\
$\mathrm{Fe}$ & $0.01 \pm 0.001$ & $0.03 \pm 0.002^{*}$ \\
\hline
\end{tabular}

Note: $\mathrm{n}=5 ; *_{-} \mathrm{P}<0.05, * *_{-} \mathrm{P}<0.01$.

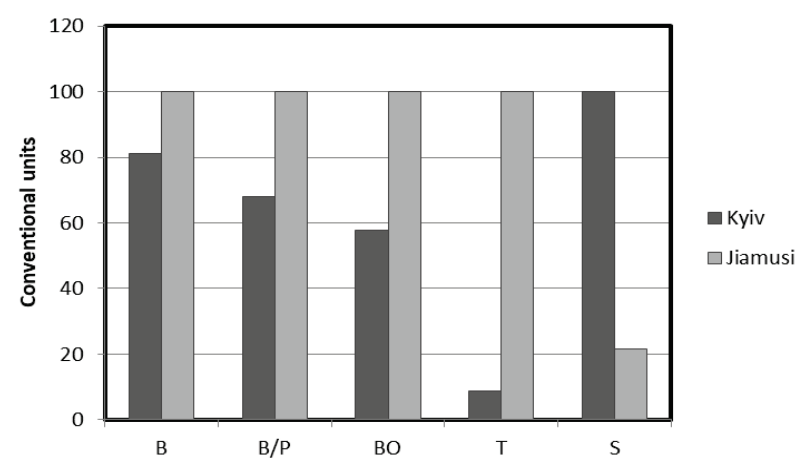

Fig. 3. Conventional units of some classes of organic compounds in soil samples of experimental plots: $\mathrm{B}$ - phenols and benzoic acids, $\mathrm{B} / \mathrm{P}$ - derivatives of pyran or oxybenzoic acids, $\mathrm{BO}$ - oxybenzoic acids, $\mathrm{T}$ - terpenoides, $\mathrm{S}$ - sterols

The obtained dependence testifies to the active development of soil microorganisms that enrich the rhizosphere of Actinidia plants with biologically active compounds and basic elements of mineral nutrition. In addition, the presence in the soil of benzoic, oxybenzoic and triterpenic acids indicates the high biological activity of plants $A$. arguta, whose rhizosphere is enriched by these compounds under the influence of extracts secreted by the roots. Unfortunately, almost nothing is known about the mechanisms of the influence of the rhizosphere microorganisms on the absorption of nutrients by the root system of plants. The resulting dependence indicates the active development of soil microorganisms that enrich the kiwiberry rhizosphere with biologically active compounds and nutrients. In addition, the presence of benzoic, hydroxybenzoic and triterpenic acids in the soil indicates the high allelopathic potential of kiwiberry. The revealed tendency in the distribution of nutrients in the kiwiberry leaves is consistent with the results obtained by the analysis of the total content of mineral elements in soil samples from experimental sites (Table 2).

Table 2

Gross content $(\mathrm{mg} / \mathrm{kg})$ of mineral elements in soils of test areas

\begin{tabular}{lccccccccc}
\hline \multirow{2}{*}{ Exposition area } & \multicolumn{7}{c}{ Elements } \\
\cline { 2 - 8 } & $\mathrm{Al}$ & $\mathrm{Ca}$ & $\mathrm{Fe}$ & $\mathrm{K}$ & $\mathrm{Mg}$ & $\mathrm{Na}$ & $\mathrm{P}$ & $\mathrm{S}$ & $\mathrm{Si}$ \\
\hline Kyiv, grey forest soil & 29970 & 5072 & 2930 & 4574 & 3608 & 3172 & 276 & 455 & 411 \\
Jiamusi, black earth & $11700^{*}$ & $6468^{*}$ & $8963 *$ & $2354^{*}$ & $1909 *$ & $2928^{*}$ & $219^{*}$ & $421^{*}$ & $350^{*}$ \\
\hline Note: $\mathrm{n}=5$; * $\mathrm{P}<0.05$.
\end{tabular}

Of particular note is the fact that there is a high concentration of silicon in the leaves of kiwiberry grown in Ukraine. Evidently it may be associated with a drought stress due to the prolonged drought period observed during the growing season of 2018 in Kyiv. In particular, the yearly amount of precipitation in Kyiv was 444 mm, and in April, during the period of active development of plants, the amount was only $8 \mathrm{~mm}$, in August $-22 \mathrm{~mm}$, in October - $17 \mathrm{~mm}$. While in Jiamusi, the total rainfall was more than $580 \mathrm{~mm}$. The evidence that kiwiberry plants grown in Kyiv experienced water deficiency is proved also by anatomical studies of the leaves. The number of stomata per $1 \mathrm{~mm}^{2}$ of leaf sur- face of Chinese plants was within $180 \pm 9.5$ per $1 \mathrm{~mm}^{2}$. By contrast, Ukrainian ones had $152 \pm 8.1$ stomata per $1 \mathrm{~mm}^{2}$ of leaf surface. Besides, leaves of kiwiberry plants grown in Ukraine had additional integumentary formations on the lower surface, which were absent in plants cultivated in China (Fig. 4).

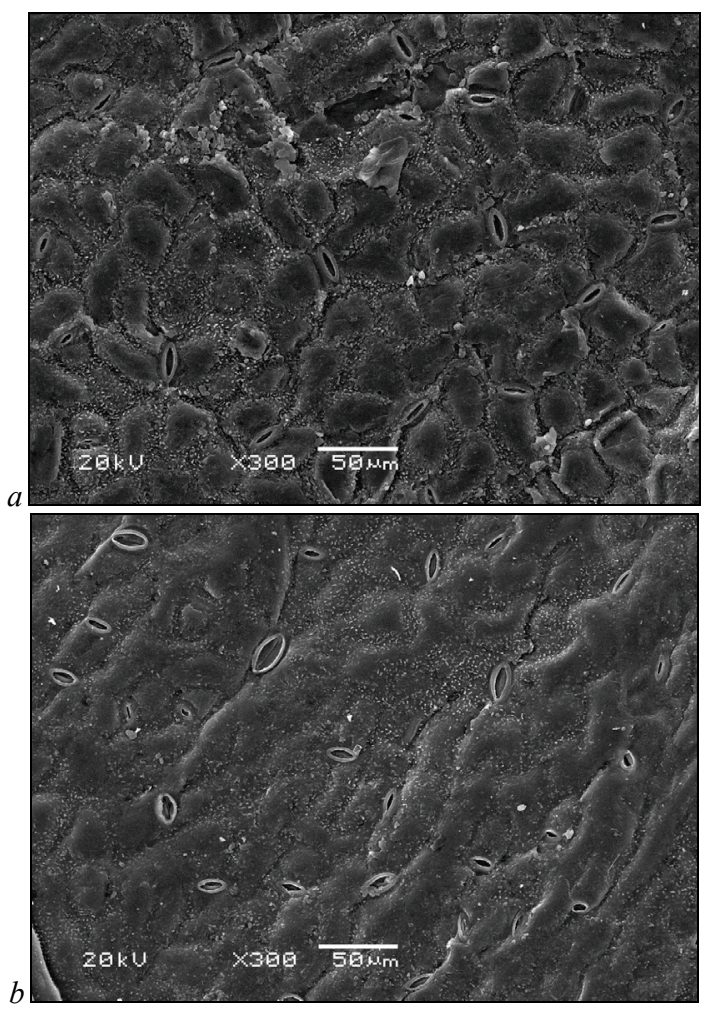

Fig. 4. Influence of soil-climatic conditions on the stomata distribution on the leaf surface: $a-$ Kyiv, $b-$ Jiamusi

High concentrations of sodium and aluminum in the kiwiberry leaves were revealed, regardless of the place of plant growth. The results obtained regarding the barrier and barrier-free entry of nutrients into plant tissues require a more detailed study.

Back in the 1960s, the localization of assimilate distribution among various organs of a plants was first proved using the carbon label technique. It was expressed in the predominance of assimilate intake from each leaf to the consuming organ closest to it.

In our study the analysis of the biogenic elements distribution between the leaves located in different layer along the kiwiberry stem revealed the following three functional layers, namely: the lower one, providing the supply of assimilates to roots; the upper one containing leaves in the phase of active growth; the middle one, redistributing the assimilates in the both directions (Table 3).

Table 3

The content of nutrients in the leaves of different stages of Actinidia plants, macroelements ( $\mathrm{mg} / \mathrm{kg}$ ), microelements (\%)

\begin{tabular}{lcccccccc}
\hline \multicolumn{1}{c}{$\begin{array}{c}\text { Stage of } \\
\text { leaves on the } \\
\text { shoot of plants }\end{array}$} & $\begin{array}{c}\mathrm{N}, \\
\mathrm{mg} / \mathrm{kg}\end{array}$ & $\begin{array}{c}\mathrm{P}, \\
\mathrm{mg} / \mathrm{kg}\end{array}$ & $\begin{array}{c}\mathrm{K}, \\
\mathrm{mg} / \mathrm{kg}\end{array}$ & $\begin{array}{c}\mathrm{Ca}, \\
\mathrm{mg} / \mathrm{kg}\end{array}$ & $\begin{array}{c}\mathrm{Mg}, \\
\mathrm{mg} / \mathrm{kg}\end{array}$ & $\begin{array}{c}\mathrm{Fe}, \\
\%\end{array}$ & $\begin{array}{c}\mathrm{Mn}, \\
\%\end{array}$ & $\begin{array}{c}\mathrm{Cu} \\
\%\end{array}$ \\
\hline \multicolumn{7}{c}{ Cultivar 'Sentyabrskaya' } \\
\hline Top & 3.68 & 0.61 & 2.87 & 1.27 & 0.58 & 298 & 66.1 & 22.1 \\
Middle & 4.11 & 0.73 & 3.24 & 2.11 & 0.71 & 343 & 72.6 & 27.2 \\
Lower & 3.84 & 0.65 & 3.13 & 1.72 & 0.65 & 329 & 70.7 & 24.3 \\
\hline \multicolumn{7}{c}{ Cultivar 'Krasunya' } \\
\hline Top & 4.35 & 0.67 & 3.42 & 1.62 & 0.35 & 271 & 76.0 & 21.9 \\
Middle & 4.81 & 0.78 & 4.09 & 2.30 & 0.51 & 325 & 82.3 & 26.4 \\
Lower & 4.56 & 0.71 & 3.97 & 1.97 & 0.47 & 308 & 89.3 & 23.9 \\
\hline \multicolumn{7}{c}{ Cultivar 'Kievskaya krupnoplodnaya' } \\
\hline Top & 3.18 & 0.58 & 3.18 & 1.49 & 1.19 & 325 & 61.9 & 22.7 \\
Middle & 3.42 & 0.68 & 3.92 & 2.01 & 1.42 & 408 & 66.4 & 29.6 \\
Lower & 3.31 & 0.62 & 3.75 & 1.65 & 1.35 & 399 & 62.2 & 24.9 \\
\hline
\end{tabular}

Note: $\mathrm{n}=5 ;{ }^{*}-\mathrm{P}<0.05$. 
Moreover, the leaves of the middle zone are characterized by a higher concentration of nutrients. Similar results were also obtained when studying the distribution of anthocyanins across the mentioned layers (Fig. 5).

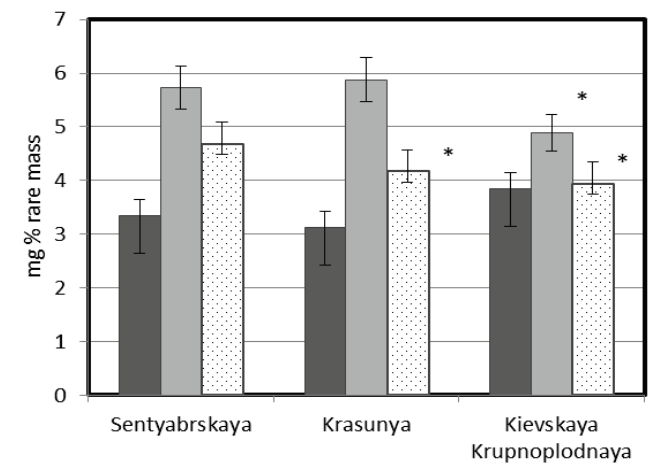

- Top stage

$\square$ Middle stage $\square$ Lower stage

Fig. 5. Anthocyanins content in leaves of Actinidia plants:

$$
\mathrm{n}=5 ; *-\mathrm{P}<0.05
$$

The analysis of the distribution of surface biopotentials in leaves across the mentioned layers as well as content of photosynthetic pigments showed a positive relationship between both these indices, especially for the leaves of the middle layer (Table 4).

Table 4

Quantitative indicators of photosynthetic pigments in Actinidia leaves during the period of active growth

\begin{tabular}{|c|c|c|c|c|}
\hline \multirow{3}{*}{ Stage } & \multirow{3}{*}{$\begin{array}{l}\text { Amplitude of } \\
\text { bioelectrical } \\
\text { potentials, } \mathrm{mV}\end{array}$} & \multicolumn{3}{|c|}{$\begin{array}{l}\text { The content of photosynthetic } \\
\text { pigments, mg/g rare mass }\end{array}$} \\
\hline & & \multicolumn{2}{|c|}{ chlorophyll } & \multirow{2}{*}{ carotenoids } \\
\hline & & $a$ & $b$ & \\
\hline \multicolumn{5}{|c|}{ Variety 'Sentyabrskaya' } \\
\hline Top & $60 \pm 5$ & $13.41 \pm 0.45$ & $5.74 \pm 0.21$ & $2.41 \pm 0.37$ \\
\hline Middle & $100 \pm 15$ & $14.12 \pm 0.31$ & $8.03 \pm 0.44 *$ & $1.94 \pm 0.05$ \\
\hline Lower & $80 \pm 10$ & $14.03 \pm 0.28$ & $7.54 \pm 0.41$ & $2.31 \pm 0.42$ \\
\hline \multicolumn{5}{|c|}{ Variety 'Krasunya' } \\
\hline Top & $40 \pm 5$ & $12.84 \pm 0.33$ & $5.01 \pm 0.22$ & $2.51 \pm 0.28$ \\
\hline Middle & $80 \pm 10$ & $13.22 \pm 0.34$ & $5.62 \pm 0.13$ & $1.83 \pm 0.09$ \\
\hline Lower & $60 \pm 5$ & $13.12 \pm 0.46$ & $5.22 \pm 0.34$ & $2.45 \pm 0.15$ \\
\hline \multicolumn{5}{|c|}{ Variety 'Kievskaya Krupnoplodnaya' } \\
\hline Top & $120 \pm 15$ & $11.01 \pm 0.36$ & $3.82 \pm 0.12$ & $2.45 \pm 0.41$ \\
\hline Middle & $160 \pm 20$ & $13.04 \pm 0.31 *$ & $5.94 \pm 0.34 *$ & $2.27 \pm 0.32$ \\
\hline Lower & $140 \pm 15$ & $12.83 \pm 0.29$ & $5.18 \pm 0.26^{*}$ & $2.14 \pm 0.25^{*}$ \\
\hline
\end{tabular}

Note: $\mathrm{n}=5, *-\mathrm{P}<0.05$.

The obtained results confirm the hypothesis of relative autonomy and the complementary role of different foliar layers in woody vines. Consequently, the described physiological differences in kiwiberry leaves located in different layers suggest also their functional differentiateons. In particular, the leaves of the lower layer perform a storage function. The middle layer is less conservative, and it is characterized by higher sensitivity to environmental factors. We identified it as a synthesis zone. The upper layer is a zone of active growth.

The results of the comparative analysis of the indices of the chloroplasts number per mesophyll cell among the studied kiwiberry cultivars revealed a significant positive correlation with the cultivar productivity (Fig. 6, 7). Therefore, we suggest that the chloroplast index could be used as a diagnostic criterion in predicting productivity of kiwiberry at an early stage of its development. It is known that higher content of chloroplasts in the mesophyll cells positively affect both adaptive capacity and productivity of higher plants.

Thus, for the first time, the regularities of distribution of nutrients and assimilates in the leaves of kiwiberry cultivars were revealed. The results obtained confirmed the hypothesis regarding the functional differentiation of plant organs between different layers. Close relation between the electrophysiological and morphological characteristics of kiwiberry leaves depending on their layer was found. In addition, it was suggested to use chloroplast's index as a marker of the productivity of kiwiberry cultivars. The results obtained could be used to improve the technology for growing fruit vines across a wide range of soil and environmental conditions.

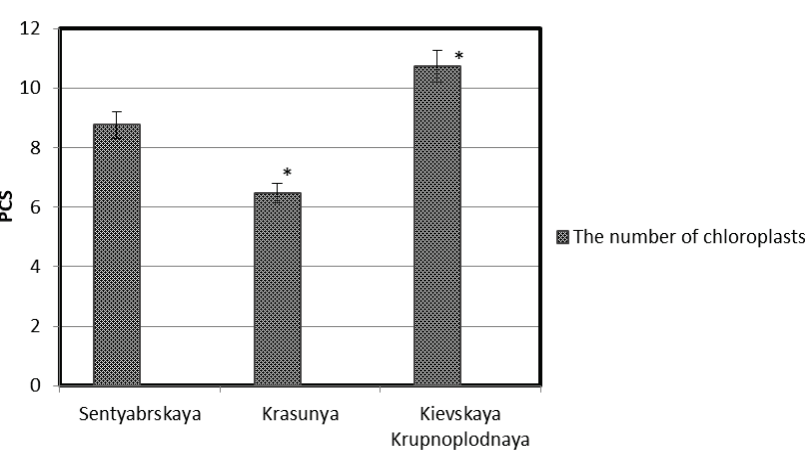

Fig. 6. The number of chloroplasts Actinidia plants: $\mathrm{n}=5 ;{ }^{*}-\mathrm{P}<0.05$

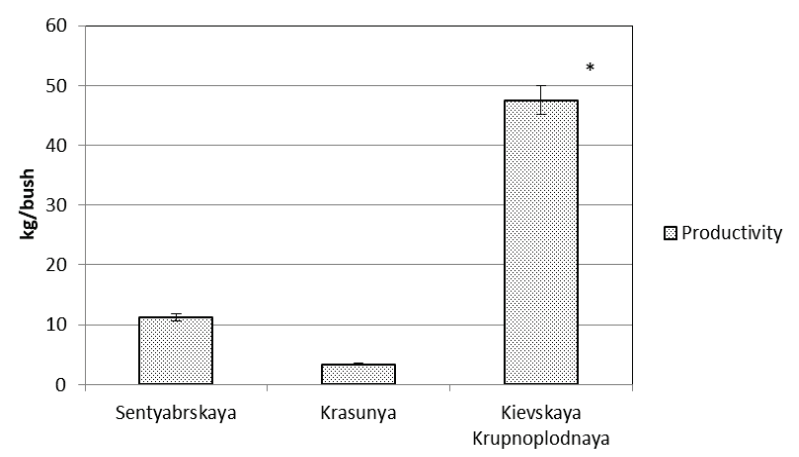

Fig. 7. Actinidia plants productivity indicators: $\mathrm{n}=5 ;{ }^{*}-\mathrm{P}<0.05$

\section{Discussion}

As a result of a comparative assessment of the content of nutrients in the leaves of kiwiberry plants grown under various soil and climatic conditions, namely in Ukraine and China, the presence of a high concentration of chlorine in the tissues was shown. Similar results were obtained by study of other species of this genus, in particular Actinidia deliciosa (A. Chev) C. F. Liang et A. R. Ferguson (Smith et al., 1987).

It is known that chlorine has a high chemical activity, improves the swelling of the protoplasm and positively affects the water content in tissues, stimulates oxidative phosphorylation. The better moisture supply of kiwiberry plants cultivated in China contributed to an increase in the concentration of chlorine in the leaves by 2.7 times in comparison with kiwiberry plants, cultivated in Ukraine.

Significant differences in the uptake of mineral elements by various cultivars of kiwiberry are also indicated (Stefanian et al., 2017). The results of our studies confirmed the high demand of $A$. arguta plants for fertile soil with a high humus content, which was also shown by other authors (Perticila et al., 2015). The revealed higher silicon content in leaves of kiwiberry grown in Kyiv could be regarded as an adaptation to drought stress. The positive role of silicon in the processes of adaptation of higher plants to the environmental stresses as well as their growth and productivity was shown in our preliminary studies (Zaimenko \& Rositska, 2018; Zaimenko et al., 2018).

Of particular interest are the data obtained in the study of surface bioelectric potentials of leaves along the stem of fruit vines. Evolution of higher plants leads to the complication and improvement of their structural organization. Adaptation to changing environmental conditions is provided by subordinate systems of organs coordinated in time and space. Periodic processes that determine the functional principle of the constitution of living systems (i.e. the principle of "stable disequilibrium" of Bauer) play an increasingly important role in the evolution of plant organisms, synchronization and coordination in time of various biochemical reactions in cells, and also determine the nature of the interaction of cells and the formation of morphostructures.

The paramount importance that bioelectric processes have in the self-regulation, adaptation and evolution processes proves the importance of the results obtained regarding the various functional roles of organs. The obtained dependence on the reintegration of assimilates turned out to be unified for plants of different ecomorphotypes. 


\section{Conclusions}

The results of the given studies showed significant differences in the distribution of assimilate between the leaves of $A$. arguta depending on the soil and climatic conditions of cultivation. The leaves of kiwiberry plants grown in China were characterized by a higher concentration of nutrients, with the exception of silicon, which is explained by the high fertility of the soil and the intense synthesis of low-molecularweight organic compounds, in particular hydroxybenzoic, benzoic and triterpenic acids. The analysis on the accumulation of mobile forms of silicon in the foliar tissues of plants grown in Ukraine indicates their stress state due to moisture deficiency in the soil. This is confirmed by xeromorphic anatomical changes, viz. the smaller number of stomata per $1 \mathrm{~mm}^{2}$ of leaf surface and formation of additional cover layer on the lower surface of the leaf blade.

The revealed accumulation of chlorine in kiwiberry tissues is consistent with the results obtained by other authors for another species of the same genus $A$. deliciosa. Noteworthy are the results on the accumulation of sodium and aluminum in the leaves of the studied kiwiberry plants, which suggests the necessity for the further studies of the peculiarities of the barrier and barrier-free entry of elements into plant organs.

For the first time, the spatial pattern of bioelectric potentials and photosynthetic activity of the foliar tissues along the stem of a woody fruit vine was analyzed. Three functional layers (the upper, middle and lower) of redistribution of assimilates and mineral elements were distinguished. In particular, the middle part had the highest concentration of macro- and microelements, indices of bioelectric potentials the content of photosynthetic pigments in comparison with the upper and lower parts.

The results obtained suggest the optimization of agricultural practices for kiwiberry cultivation, including foliar feeding. A comparative analysis of the yield of various kiwiberry cultivars made it possible to identify a diagnostic feature for the prediction of their potential productivity, in particular, by counting the number of chloroplasts in the mesophyll cells and the determining content of chlorophyll $b$.

\section{References}

Belan, L. L., Pozza, E. A., Freitas, M. L. D., Pozza, A. A., \& Alves, M. S. (2015) Nutrients distribution in diseased coffee leaf tissue. Australasian Plant Pathology, 44(1), 105-111.

Buwalda, J. G., \& Smith, G. S. (1991). Influence of anions on the potassium status and productivity of kiwifruit (Actinidia deliciosa) vines. Plant and Soil, 133, 209-218.

De Souza, A., Govea-Alcaide, E., Masunaga, S. H., Fajardo-Rosabal, L., Effenberger, F., Rossi, L. M., \& Jardim, R. F. (2019). Impact of $\mathrm{Fe}_{3} \mathrm{O}_{4}$ nanoparticle on nutrient accumulation in common bean plants grown in soil. SN Applied Sciences, 1,308

Dong, C., He, F., Berkowitz, O., Liu, J., Cao, P., Tang, M., Shi, H., Wang, W., Li, Q., Shen, Z., Whelan, J., \& Zheng, L. (2018). Alternative splicing plays a critical role in maintaining mineral nutrient homeostasis in rice (Oryza sativa). The Plant Cell, 30, 2267-2285.

Han, N., Park, H., Kim, C.-W., Kim, M.-S., \& Lee, U. (2019). Physicochemical quality of hardy kiwifruit (Actinidia arguta L. cv. cheongsan) during ripening is influenced by harvest maturity. Forest Science and Technology, 15, 187-191.

Jankowski, K., Malinowska, E., Wiśniewska-Kadżajan, B., Jankowska, J., Truba, M., Czeluściński, W., Koper, O., Góral, P., Kania, P., Matsyura, A. (2018a). The effects of soil conditioners on grass colour throughout the growing season. Applied Ecology and Environmental Research, 16(4), 3981-3992.

Jankowski, K., Truba, M., Jankowska, J., Czeluscinski, W., Wisniewska-Kadzajan, B., Malinowska, E., Koper, O., Góral, P., Kania, P., Matsyura, A. (2018b). Effects of soil conditioners on lawn grass growth in different year seasons. Applied Ecology and Environmental Research, 16(4), 3755-3765.
Kalaji, H. M., Bąba, W., Gediga, K., Goltsev, V., Samborska, I. A., Cetner, M. D., Dimitrova, S., Piszcz, U., Bielecki, K., Karmowska, K., Dankov, K., \& Kompała-Bąba, A. (2018). Chlorophyll fluorescence as a tool for nutrient status identification in rapeseed plants. Photosynthesis Research, 136(3), 329-343.

Kornienko, I. A., Maslov, S. P., \& Shilov, I. A. (1965). Nekotorye obshhie principy adaptaczii biologicheskikh sistem [On some general principles of adaptation of biological systems]. Journal of Total Biology, 26(1), 121-126.

Loza, I. M., Pakhomov, O. Y., \& Chorna, V. I. (2018). Evaluation of remediation efficiency of manganese quarry lands after open-cut mining: Ecosystem approach. Naukovyi Visnyk Natsionalnoho Hirnychoho Universytetu, 4, 122-128.

Lykholat, Y. V., Khromykh, N. O., Pirko, Y. V., Alexeyeva, A. A., Pastukhova, N. L., \& Blume, Y. B. (2018). Epicuticular wax composition of leaves of Tilia L. trees as a marker of adaptation to the climatic conditions of the steppe Dnieper. Cytology and Genetics, 52(5), 323-330.

Maillard, A., Diquélou, S., Billard, V., Laîné, P., Garnica, M., Prudent, M., Garcia-Mina, J., Yvin, J., \& Ourry, A. (2015). Leaf mineral nutrient remobilization during leaf senescence and modulation by nutrient deficiency. Frontiers in Plant Science, 137, 1-15.

Niu, Q., Shen, J., Liu, Y., Nie, C., Skrypchenko, N. V., \& Liu, D. (2019). Research progress on main active constituents and pharmacological activities of Actinidia arguta. China Academic Journal, 40(3), 333-344.

Parent, S.-E., Barlow, P., \& Parent, L. E. (2015). Nutrient balances of New Zealand kiwifruit (Actinidia deliciosa cv. hayward) at high yield level. Communications in Soil Science and Plant Analysis, 46(1), 256-271.

Peticila, A., Scaeteanu, G., Madjar, R., Stanica, F., \& Asanica, A. (2015). Fertilization effect on mineral nutrition of Actinidia deliciosa (kiwi) cultivated on different substrates. Agriculture and Agricultural Science Procedia, 6, 132-138.

Qing, W., ZhiXing, L., JingWen, Z., \& YouQing, C. (2019). Effects of lac production on the contents and distribution of nutrient elements in soil and host plants. Journal of Environmental Entomology, 41(1), 113-118.

Silva, V. M., Boleta, E. H. M., Lanza, M. G. D. B., Lavres, J., Martins, J. T., Santos, E. F., Santos, F. L. M., Putti, F. F., Junior, E. F., White, P. J., Broadleye, M. R., Carvalho, H. W. P., \& Reis, A. R. (2018). Physiological, biochemical, and ultrastructural characterization of selenium toxicity in cowpea plants. Environmental and Experimental Botany, 150, 172-182.

Šimek, J., Tůma, J., \& Feller, U. (2019). Accumulation, distribution and redistribution of ${ }^{109} \mathrm{Cd}$ and ${ }^{65} \mathrm{Zn}$ in wheat (Triticum aestivum L.) and bean (Phaseolus vulgaris L.) plants on nutrient media with elevated zinc or cadmium. Journal of Elementology, 24(3), 1129-1141.

Singh, B. R., McLaughlin, M. J., \& Brevik, E. C. (2017). The nexus of soils, plants, animals and human health. Catena-Schweizerbast, Stuttgart.

Skrypchenko, N., \& Latocha, P. (2017). The genesis and current state of Actinidia collection in M. M. Grishko National Botanical Garden in Ukraine. Polish Journal of Natural Sciences, 32(3), 513-525.

Smith, G. S., Clark, C. J., \& Holland, P. T. (1987). Chlorine requirement of kiwifruit (Actinidia deliciosa). The New Phytologist, 106(1), 71-80.

Stefaniak, J., Stasiak, A., Latocha, P., \& Łata, B. (2017). Effect of nitrogen fertilization on Actinidia arguta plants vigour and soil characteristics. Journal of International Scientific Publications, Agriculture and Food, 5, 314-323.

Volozhin, A. I., \& Subbotin, Y.K. (1987). Adaptacziya i kompensacziya-universal'nyj biologicheskij mekhanizm prisposobleniya [Adaptation and compensation is a universal biological mechanism of adaptation]. Medicina, Moscow (in Russian).

Yamaji, N., \& Ma, J. F. (2014). The node, a hub for mineral nutrient distribution in graminaceous plants. Trends in Plant Science, 19(9), 556-563.

Zaimenko, N. V. (2008). Naukovi pryntsypy strukturno-funktsionalnoho konstruiuvannia shtuchnykh bioheotsenoziv u systemi hrunt-roslyna-hrunt [Scientific principles of structural-functional design of artificial biogeocoenoses in soilplant-soil system]. Naukova Dumka, Kyiv (in Ukrainian).

Zaimenko, N. V. (2019). Thermodynamical aspects of the introduction processes. Plant Introduction, 81, 3-7.

Zaimenko, N. V., \& Rositska, N. V. (2018). Role of nanomaterials of analcime, Tripoli and silicon dioxide in plants under drought conditions in Tritium aestivum L. Ecologia Balcanica, 10(1), 1-9.

Zaimenko, N. V., Didyk, N. P., Pavliuchenko, N. A., Ivanytska, B. O., Kharytonova, I. P., \& Rositska, N. V. (2018). Natural silicates mixed with organic fertilizers enhance corn adaptation to salt stress and improve physical characteristics of sandy soil. Journal of Crop Improvement, 20, 188-207. 